\title{
The impact of intellectual capital, organizational capabilities and innovation on firm performance of textile sector: a moderating effect of GSP Plus
}

DOI: $10.35530 / 1 T .070 .06 .1632$

\author{
MUHAMMAD ZIA-UR-REHMAN \\ SAJJAD AHMAD BAIG \\ MUHAMMAD ABRAR \\ MUHAMMAD HASHIM
}

\author{
FIZA AMJAD \\ IRFAN AHMAD BAIG \\ MUHAMMAD USMAN
}

\section{ABSTRACT - REZUMAT}

\begin{abstract}
The impact of intellectual capital, organizational capabilities, and innovation on firm performance
\end{abstract} of textile sector: a moderating effect of GSP Plus

\begin{abstract}
The objective of this study was to investigate the relationship between intellectual capital, organizational capabilities, Innovations and firm performance through the moderating role of GSP Plus status. The findings show that intellectual capital, organizational capabilities, and Innovations have a significant impact on firm performance. Additionally, the GSP Plus moderates the relationship between intellectual capital and firm performance. The GSP Plus also moderates the relationship between Innovation and firm performance. However, GSP Plus does not moderate the relationship between organizational capabilities and firm performance. The findings of this study would guide the textile exporters to understand how to enhance a firm's performance by giving preference to the intellectual capitals, Organizational Capabilities and Innovations and how to utilize the GSP Plus status effectively.
\end{abstract}

Keywords: GSP Plus, intellectual capital, performance, Organizational Capabilities

Impactul capitalului intelectual, capacităților organizaționale și inovării asupra performanței firmelor din sectorul textil: un efect de moderare GPS Plus

Obiectivul acestui studiu a fost de a investiga relația dintre capitalul intelectual, capacitățile organizaționale, inovarea și performanța firmelor prin rolul moderator al GSP Plus. Rezultatele arată că inovarea, capitalul intelectual şi capacitățile organizaționale au un impact semnificativ asupra performanței firmei. În plus, GSP Plus moderează relația dintre capitalul intelectual și performanța firmelor. GSP Plus moderează, de asemenea, relația dintre inovare și performanța firmelor. Totuși, GSP Plus nu moderează relația dintre capacitățile organizaționale și performanța firmelor. Rezultatele acestui studiu îi vor îndruma pe exportatorii de textile să înțeleagă cum să îmbunătățească performanța unei firme, acordând importanță capitalului intelectual, capacităților organizaționale și inovării și cum să utilizeze în mod eficient GSP Plus.

Cuvinte-cheie: GPS Plus, capital intelectual, performanță, capacități organizaționale

\section{INTRODUCTION}

The oldest, biggest, and commercial industry in the world is the textile and clothing industry. Most of the textile industries throughout the world are labor-intensive. The textile sector of Asia had always been grabbing the attention of thewell-developed countries of the west. Pakistan is the principal exporter of cottonbased fabric, Fabric products, and cotton. At present, Pakistani fabric products have been encountering challenging competition by major competitors like India, Bangladesh, and China [1]. Textile exports value of China is about US\$ 45 million and of Pakistan US\$ 13.8 million. It is a major source of employment generation in Pakistan.

"Generalized System of Preferences is a mechanism of a formalized system through which the developed countries like the USA and the European Union give relaxation in tariffs to the underdeveloped countries, which have the membership of WTO to export their goods to Europe or the USA". According to Kaufmann \& Schneider [2], intellectual capital has defined in different ways, such as, there is concurrence about the value creation of IC and its supports in creation of competitive advantages in organizations. Authors define organizational capabilities as "Capabilities are complex bundles of skills and knowledge embedded in generational processes" [3]. Innovation was classified into five types, namely, products, processes, technological, markets, and organizational innovation. This study considers two dimensions of innovation: technological innovation and administrative innovation. This study is designed to examine whether the possibilities and challenges, placed on the GSP+ status have any influence on the Performance of the textile industry of Pakistan? What sorts of the role will the GSP+ status will play in the fulfillment of the textile industry? Moreover, how the development of the 
textile sector can be achieved by focusing on intellectual capital, organizational innovation, and capabilities? The primary objectives are comprehensive to study the role of GSP Plus status on the performance of the Pakistani textile industry.

\section{LITERATURE REVIEW}

\section{Intellectual Capital (IC)}

According to Cohen \& Kaimenakis [4], IC is the integration of internal and external knowledge of the firms that provide a viable competitive advantage, if it is undertaken by the well-managed firm. According to Tseng \& James Goo [5], intellectual capital and the firm market value have a positive and significant effect on financial performance. Australian banks which heavily invest in the components of intellectual capital are more profitable than others who have low investment in IC [6]. The empirical evidence suggests that profitability, market valuation and productivity of the company in South Africa would be explained by the performance of its intellectual capital [7].

Hypothesis 1: There is a positive and significant relationship between the intellectual on firms performance.

\section{Organizational Capability}

Authors define organizational capabilities as "Capabilities are complex bundles of skills and knowledge embedded in generational processes [3]". According to the functional definition of organizational capability, there are seven dimensions of organizational capabilities, i.e., learning, R\&D, resource allocation, marketing, organizing, structural planning, and manufacturing capabilities [8]. The resourcebased perspective of the firm contends that capabilities are supportive for enhanced quality, and decreased irregularity, are the foundation of the upper hand [9].

Hypothesis 2: There is a positive and significant relationship between organizational capabilities and firms' performance.

\section{Innovation}

Innovation was classified into five types, namely, products, processes, technological, markets, and organizational innovation. This study considers two dimensions of innovation: technological innovation and administrative innovation. The new product and technological development had a significant impact on the performance of firms [10].This study determined the importance of innovation for the survival of businesses in today's competitive world and their potential growth with a particular example of organic textile. The findings of this study would help the countries of the developing world, exclusively Pakistan, to successfully exploit organic textile opportunities for creating competitive advantage and growth available in the international markets [11-12]. The scholar suggests that innovation is used as a competitive strategy by Pakistani respondents to compete globally. The main source of technical innovation is the internal innovation in firms Pavitt [13] and typical internal innovation depends on the capability of workers. Administrative innovations can be described as the new techniques, rules and structure forms [14]. Innovation is one of the most crucial drivers of longrun success in business, notably in rapidly changing markets. On the basis of the literature review, the study develops the following hypothesis.

Hypothesis 3: There is a positive and significant relationship between innovation and firms' performance.

\section{GSP Plus and Firm Performance}

Internationalization is an important growth strategy for the firms whose home country market is limited, though it enables the firms to realize economies of scale and scope Caves \& Caves [15], increase their market power [16]. According to Pasha [17], European Union's award, the status of Generalized System of Preferences (GSP) to Pakistan allow the duty-free access for several eligible categories of Products, manufactured in Pakistan which were exported to the EU market. Scholer suggested that the Pakistani industry would invest in capacity building for their employees to increase their performance[18].

Many studies show that opportunities of international trade had a positive impact on firms' performance. Opportunities for import and export are more productive than non-export and non-import, and they were more versatile and more productive as compared to their own performance when they were not importer and exporter [19].

H4: GSP plus moderates the relationship between structural capital and firms' performance.

H5: GSP plus moderates the relationship between organizational capabilities and organizational performance.

H6: GSP plus moderates the relationship between innovations and firms' performance

\section{METHODOLOGY}

\section{Data types and research period}

From the literature, it was shown that the most frequently used technique for data collection in quantitative research methodology is surveyed questionnaire. Keeping in mind all constraints (cost, time, and population), mail survey and self-administered questionnaire were adopted for the data collection, from the textile companies of Pakistan. The targeted population for this study is the executives, General Managers, Marketing Managers, Mill Managers, Finance Managers and other managers of Pakistani textile companies; and these executives and managers have sufficient knowledge and access to the internet. The primary data were collected from the textile sector of Pakistan. The respondents were selected from four categories of textile sector, i.e., Spinning, Weaving, Processing, and Garments from two provinces of Pakistan, i.e., Sindh and Punjab. All necessary details about textile companies were 
taken from these associations' members' directory. Multistage sampling technique will be used to select respondents, and the sample size is around 450 . After a brief overview of the literature, a developed questionnaire was selected for the study that was the most relevant to this research objective. The measure was adjusted in the context of the study. The current study dealt with innovation, organizational capabilities, firm performance and GSP plus. Prior to the start ofthe survey, a pilot study was conducted. The main purpose of the pilot study is to developan understanding of the respondents about the questions, used in survey andto implore response for the improvement of the measuresand determine the time, required for the completion of a survey by the respondents.

\section{Data analysis}

AMOS software was used to find out the relationship between endogenous and exogenous constructs. The study used confirmatory factor analysis to assess the reliability and validity of measures.

\section{Confirmatory Factor Analysis}

The measure, used for human capital and structural capital consists of eight items, and for customer capital 6 items: for each uses a seven-point Likert-scale to obtain responses, ranging from 7 for strongly agreed to 1 for strongly agreed. Although the instruments were previously tested for validity and reliability, and the reliability coefficients for human capital was $\alpha=0.643$, for structural capital $\alpha=0.754$, and for customer capital 0.677 . The organizational capability has seven dimensions with 30 items: the results of reliability coefficients for Learning Capability $\alpha=0.746$, R\&D $\alpha=0.791$, Organizing capability $\alpha=0.828$. Marketing Capability $\alpha=0.782$, Manufacturing Capability $\alpha=0.700$ and for Strategic Planning $\alpha=0.792$. The Innovation constructs have two dimensions, e.g., technical innovation and administrative innovation was represented by 6 items. The Reliability analysis shows that reliability coefficients for technological innovation were $\alpha=0.70$, and for administrative innovation $\alpha=0.758$. To measure the performance, the study used an already developed measure scale by Khalique et al. [20]. Subjective measures can be consistent with objective measures, indicated by the previous researchers. The reliability coefficient for measuring performance was $(\alpha=0.816)$. For better understanding, loadings that are above 0.70 are considered. All items loaded on their respective factor loading and most of the loadings above 0.70 as shown in the table. The results of CFA suggest that $(\mathrm{CMIN} / \mathrm{DF}=4.53, \mathrm{RMESA}=0.051$, $\mathrm{CFI}=0.939, \mathrm{TLI}=0.914$ and $\mathrm{IFI}=0.939)$ the model was accepted without any modification. As the results of CFA exhibited, a strong Loading and the model showed a good model fit for Data. The fit indices of the model show that related to the suitability of the fit raised $R M E S A$ and $x^{2}$.

\section{Model Testing}

ASEM was used to test the direct path model and the hypnotized moderating relationship.

\section{Direct Path Testing}

This study used SEM to test the model, firstly examine the direct relationship between Intellectual capital and firm performance, organizational capability and firm performance and also the relationship between innovation and firm performance. According to the results of SEM, the path between intellectual capital and firm performance is positive and significant with positive $\beta$ value 0.51 and $p>0.05$. The results of AMOS are $(\beta=0.51, p=000)$. These findings support the H1. The results demonstrate that organizational capabilities positively and significantly contribute to firm performance $(\beta=0.149, p=0000)$. These results showthat 1 percent change in organizational capabilities contributes 14.9 percent in firm performance, $\mathrm{H} 2$ is accepted. The results also show that innovation positively and significantly impacts firm performance $(\beta=0.172, p=0000)$. Beta value shows that 1 percent change in innovation activities leads to $17.2 \%$ change in firm performance. So the H3 is accepted.

\section{Table 1}

SUMMARY OF INITIAL PATH MODEL ANALYSIS

\begin{tabular}{|c|c|c|c|c|}
\hline \multicolumn{1}{|c|}{ Indicators } & $\begin{array}{c}\text { Estimate/ } \\
\boldsymbol{\beta}\end{array}$ & S.E. & C.R. & $\mathbf{P}$ \\
\hline PERORM $\leftarrow$ OC & 0.511 & 0.052 & 11.892 & 0.000 \\
\hline PERORM $\leftarrow$ Innovation & 0.172 & 0.044 & 4.212 & 0.000 \\
\hline PERORM $\leftarrow$ IC & 0.149 & 0.058 & 3.735 & 0.000 \\
\hline R & 0.514 & \multicolumn{3}{|c}{} \\
\hline
\end{tabular}

\section{Intellectual capital and firm performance}

The product term of intellectual capital ${ }^{*}$ GSP plus was showing a positive and significant impact on firm performance $(\beta=0.169, p=0.051)$. Hence, it supports the fourth hypothesis; the results indicate that the model described $63 \%$ variance in firm performance. The resultssupport the relationship between the interaction term of IC*GSP and firm performances. H4 is accepted.

Table 2

\begin{tabular}{|c|c|c|c|c|}
\hline Indicators & $\begin{array}{c}\text { Path } \\
\text { coefficients }\end{array}$ & S.E. & C.R. & $\mathbf{P}$ \\
\hline IC & -0.299 & 0.233 & -1.285 & 0.199 \\
\hline GSP & 0.128 & 0.045 & 2.823 & 0.005 \\
\hline Int_1 & 0.169 & 0.220 & 0.768 & 0.051 \\
\hline $\mathrm{R}^{2}$ & \multicolumn{4}{|c|}{0.63} \\
\hline
\end{tabular}




\section{Organizational Capabilities}

The product term of $\mathrm{OC}^{*} \mathrm{GSP}$ plus was showing a positive but insignificant impact on firm performance $(\beta=0.032, p=0.995)$. Hence, it does not support the fourth hypothesis as the results indicate that the model described $72 \%$ variance in firm performance. The results show that the relationship between the interaction term of IC*GSP and firm performances is positive but insignificant. H5 is rejected.

Table 3

ESTIMATED SEM RESULTS OF PRODUCT TERMS OF OC*GSP

\begin{tabular}{|c|c|c|c|c|}
\hline Indicators & Estimates & S.E. & C.R. & p \\
\hline OC & 0.505 & 0.168 & 2.999 & 0.003 \\
\hline GSP & 0.650 & 0.162 & 4.015 & 0.000 \\
\hline Int_1 & 0.002 & 0.032 & 0.056 & 0.955 \\
\hline R $^{2}$ & \multicolumn{4}{|c|}{0.72} \\
\hline
\end{tabular}

\section{Innovation}

In the progress of the organization, the role of innovation is crucial and stimulating the standards of living. This section explores two significant types of innovation, i.e., technical innovation and administrative innovation of textile industry. The product term of Innovation*GSP plus was showing a positive and significant impact on firm performance $(\beta=0.087$, $p=0.016)$. Hence, it does not support the fourth hypothesis as the results indicate that the model described $61 \%$ variance in firm performance. The significance value $p=0.016$ and beta value 0.087 which show that the relationship between interaction term of IC*GSP and firm performances positive and significant. $\mathrm{H} 6$ is accepted.

$\mathrm{R}^{2}$ was 0.610 . The interaction term (GSP*innovation) was significant. All the results approved that status of GSP plus moderated the relationship between innovation and firm performance. These results were also proved with a model run by employing AMOS SEM. Moreover, hence, the study accepts the hypothesis that GSP plus moderate the relationship between innovation and firms' performance.

Table 4

ESTIMATED REGRESSION RESULTS OF PRODUCT TERM OF INNOVATION*GSP

\begin{tabular}{|c|c|c|c|c|}
\hline Indicators & Estimates & S.E. & C.R. & p \\
\hline Innovation & -0.210 & 0.181 & -1.164 & 0.244 \\
\hline GSP & 0.350 & 0.181 & 1.929 & 0.054 \\
\hline Int_1 & 0.087 & 0.036 & 2.398 & 0.016 \\
\hline R $^{2}$ & \multicolumn{5}{|c|}{0.61} \\
\hline
\end{tabular}

\section{DISCUSSION}

The study aimed to explore the association between IC, OC, Innovation, firm performance and the moder- ating role of GSP Plus. The findings suggest that the combination of three elements of intellectual capital waspositively contributed to the performance of the textile industry in Pakistan. The findings of this study were approved by previous studies. The organizations, invested in intellectual capital especially in human capital are performed well. There is no doubt that intellectual capital is considered one of the critical factors and a key driver for organizational performance [20-21]. Pakistan has not well-organized its knowledge ofthe economy. Pakistan does not rank highly among the world's knowledge-intensive nations [22]. Chen, Moghaddas, Hoppel, \& Lesnefsky [23] and Miller \& Wurzburg [24] also have similar findings; they concluded that intellectual capital positively and significantly contributes to firms' performance. It is also found that intellectual capital can be further increased through capacity building of employees. However, formal investment in training and development among Pakistani textile industries, especially in SMEs is miserably low. The results show that organizations that understand the importance of GSP Plus and willing to invest in intellectual capital would perform better. In the history, Sri Lanka benefited from the GSP plus scheme that extended trade incentive to the textile sector to enter into European Union (EU) market. According to Ekanayake [25], he suggested that companies perform better under GSP era and increase their exports. These studies provide evidence that GSP plus Status help organizations to enhance their performance. According to Qureshi \& Jalbani [26], technological capacity-building and financial assistance help organizations to move toward the global expansion in different sectors of Pakistan. The GSP plus status encourages globalization of their operations and boosts their share of export in the world market. When the value of GSP plus increased its effects positively on the relationships between Intellectual Capital and firms' performance. While the combination of Organizational Capabilities positively and significantly affectsfirms' performance. According to Grewal \& Slotegraaf [27], organizational capabilities empower a firm to perform well, and OC lives in organizational process and schedules that are hard to imitate. Capabilities are profoundly established in these procedures and accordingly are inserted inside of firms in the mindboggling cross section of interconnected activities that take subsequent administrative choices after some time. Danneels [28] also reveals similar findings; he concluded that current capabilities might serve as influences, focusing on the development of new ones for sustaining the firms' performance. In general, capabilities were key determinants of firms'performance; there was a positive and significant relationship between OC and firm performance [29]. The results were partially supported by Autio, Sapienza, \& Almeida [30], as they concluded that normally capabilities are passively linked with performance and with international trade opportunities. In addition, it was also interesting results in short run that organizations investment on the capabilities in 
the initial stage of internationalization (international trade opportunities) might have an insignificant effect on firms' performance and might be reduced the chances of a firm's performance in short run. Also Sapienza, Autio, George, \& Zahra [31] stated that, when firms were starting to develop capabilities, the organization was fragile in early stages and these new capabilities became more effective, workable and profitable in the long run. This study hypothesized that innovations positively correlated with firms' performance. Findings of the study reveal that innovations positively and significantly affect firm performance. Gunday, Ulusoy, Kilic, \& Alpkan [32] also found that innovations positively affectthe organizational performance of manufacturing industries. The effect of the knowledge management capabilities on firm performance isfully mediated by innovations [33]. They concluded that innovation significantly and positively affects firms' performance of the textile sector. Qiao, Ju, \& Fung [34], they investigated that innovation was found a positive effect on firms' performance at SMEs. According to Soto-Acosta, Popa, \& Palacios-Marqués [35], innovations positively contributed to firms' performance. Another researcher Gunday et al. [32] studied that different types of innovation had a significant positive effect on firms' performance of manufacturing industries. Ceylan [36] found that Administrative innovation activities were the main forces for implementing the process of innovation and marketing innovation, resulting in more innovative products. Subsequently, product innovation would enhance firms' innovation performance. The previous studies provide support to the findings. The organizational supports for the advancement of technical capabilities, firm performance can be increased through organizational innovations and technical capabilities, used in processes and products [37]. Alamdari \& Fagan [38] examine the linkage between innovation in production and firms' performance. Previous studies explore that lead-time and innovative product development behavior and the process of production positively impactedon the firm performance. According to Cingöz \& Akdoğan [39], in an ever-changing business environment, the innovative behavior of production positively links the firm performance, which is considered as an important source that leads the organization toward success. Another scholar suggested that superior firm performance can be achieved through organizational innovation and technological capabilities for the products and processes [37].

According to Miller [40], mostly the organizations adapt technological innovation for improving firms' performance by attaining the competitive advantages in their markets. However, the technological innovation required the support of marketing and organizational innovation. Walker [41] stated that a sustainable adoption of both technical and administrative were more efficient in helping the organization to sustain and improve their performance as compared to one type of innovation in an organization. Although innovation literature and our results were unable to describe a decision whether a specific innovation type was likely to provide more or less impact on the performance of manufacturing units, so it can be concluded that the different types of innovations influence each other and need to be implemented in conjunction. Therefore, for boosting exports, it is suggested to implement both types of innovations are in conjunction.

This result also enhances the innovation literature by proving that another significant factor that international trade opportunity strengthens the relationship between innovation and performance of organizations. The findings were supported by the findings of Kafouros, Buckley, Sharp, \& Wang [42], who concluded that the impact of the different innovation practices on the organizational performance is statistically insignificant for those firms, having fewer trade opportunities internationally.

\section{CONCLUSION}

This study was designed to examine whether the opportunities and challenges, placed by the GSP+ status had any influence over the Performance of the textile industry. What sorts of role would the GSP+ status play in the performance of the textile industry? Moreover, how the development of Textile sector could be achieved by focusing on the intellectual capital and Organizational innovation and capabilities. The main objectives were to study the role of GSP Plus status on the performance of Pakistan's Textile industry comprehensively. For studyingthe role of GSP Plus status in the performance of Pakistan's Textile industry comprehensively, we studied the capability of a Textile sector of Pakistan for getting the benefits of GSP Plus status; investigate the strength of Textile sector regarding the development of intellectual capital to exploit GSP Plus. To explore how the innovations can be important to develop the textile sector to get benefits of GSP Plus status.

This study measures the intellectual capital by the value of Human capital, structural capital and, customer capital. According to the results, there was a positive relationship with firm performance. The current study measures Organizational Capability through seven dimensions: Learning Capability, Marketing Capability, R\&D Capability, Resource Allocation Capability, Manufacturing Capability, Organizing Capability, and Strategic Capability. According to the results, organizational capabilities showeda positive relationship with the firms' performance. However, after introducing GSP plus as a moderator, the relationship became insignificant. In today's dynamic business environment, organizations need to focus equally on all the organizational capabilities, mostly organizations focused on marketing capabilities and ignored all other OC. They must align all type of capabilities with business strategies to be competitive in the global market. We measure innovation through two dimensions: administrative innovation and firms' performance. According to results of regression analysis showed that there was 
a positive and significant relationship between Innovation and firm performance. So, for boosting exports, it is suggested to implement both types of innovations in conjunction. This study also examined the impact of innovation on textile performance in the context of the GSP Plus for Pakistani textile organizations. The results indicated that the interaction term of innovation*GSP had a positive and highly significant impact on the dependent variable (firm performance).

\section{Limitation of study}

This study also has some limitations. The current study collected data from the overall textile sector of Pakistan without specifying any industry like Garment, Processing, Weaving, Spinning, and Knitting. The GSP plus status would help to improve the export performance of the textile sector of Pakistan. Therefore, there is a need to consider export-oriented textile industries to boost export performance. We should also consider other manufacturing industries, which come under the scope of GSP plus. Secondly, the current study utilized crosssectional data, which makes it problematic to explain complete cause-effect relationships between constructs. Longitudinal research in the future is required; which make it possible to understand inferences. There might be other variables, which could boost the export performance of manufacturers through GSP plus scheme like HR Practices, learning orientation, Organizational Culture, TQM Practices, and Knowledge Exchange. The main advantage of GSP plus status is to improve the export performance of organizations; however; the current study worked on overall organizational performance. Therefore, future research must focus on export performance in order to exploit completely an organizational performance.

\section{REFERENCES}

[1] Shahbaz, M., Measuring economic cost of electricity shortage: current challenges and future prospects in Pakistan, 2015

[2] Kaufmann, L., Schneider, Y., Intangibles: a synthesis of current research, In: J. Intellect. Cap., 2004, 5, 3, 366-388

[3] Helfat, C.E., Peteraf, M.A., The dynamic resource-based view: Capability lifecycles, In: Strateg. Manag. J., 2003, 24, 10, 997-1010

[4] Cohen, S., Kaimenakis, N., Intellectual capital and corporate performance in knowledge-intensive SMEs, In: Learn. Organ., 2007, 14, 3, 241-262

[5] Tseng, C., James Goo, Y., Intellectual capital and corporate value in an emerging economy: empirical study of Taiwanese manufacturers, In: R\&D Manag., 2005, 35, 2, 187-201

[6] Pulic, A., VAIC ${ }^{T M}$ - an accounting tool for IC management, In: Int. J. Technol. Manag., 2000, 20, 5-8, 702-714

[7] Firer, S., Mitchell Williams, S., Intellectual capital and traditional measures of corporate performance, In: J. Intellect. Cap., 2003, 4, 3, 348-360

[8] Yam, R.C.M., Guan, J.C., Pun, K.F., Tang, E.P.Y., An audit of technological innovation capabilities in Chinese firms: some empirical findings in Beijing, China, In: Res. Policy, 2004, 33, 8, 1123-1140

[9] Barney, J., Firm resources and sustained competitive advantage, In: J. Manage., 1991, 17, 1, 99-120

[10] Mumford, M.D., Managing creative people: Strategies and tactics for innovation, In: Hum. Resour. Manag. Rev., 2000, 10, 3, 313-351

[11] Safeer, A.A., Basit, A., Abrar, M., Zia-Ur-Rehaman, M., Baig, S.A.,Hashim, M., Export competitiveness analysis of Pakistan garments industry based on GEM Model, In: Industria Textila, 2018, 69, 3, 219-229, https://doi.org/ 10.35530/IT.069.03.1457

[12] Abrar, R., Safeer, M.,Baig, A.A., Bashir, S.A., Amjad, F., Shabbir, R., Innovation is creating competitive advantage: a perspective to improve the organic textile products for business growth, In: Industria Textila, 2019, 70, 2, 147-153, https://doi.org/10.35530/IT.070.02.1644

[13] Pavitt, K., What we know about the strategic management of technology, In: Calif. Manage. Rev., 1990, 32, 3, $17-26$

[14] Evan, W.M., The organization-set: Toward a theory of interorganizational relations, In: Approaches to Organ. Des., 1966, 173-191

[15] Caves, R.E., Multinational enterprise and economic analysis, Cambridge university press, 1996

[16] Kogut, B., Designing global strategies: profiting from operational flexibility, In: Readings Int. Business, MIT Press. Cambridge, MA, 1993, 195-213

[17] Pasha, H.A., GSP plus status and compliance of labor standards, Friedrich-Ebert-Stiftung, 2014

[18] Wagan, S.M., Export boost of Textile Industry of Pakistan by availing EU's GSP Plus, In: J. Econ. Libr., 2015, 1, $1,18-27$

[19] Wagner, J., German multiple-product, multiple-destination exporters: Bernard-Redding-Schott under test, In: University of Lüneburg Working Paper Series in Economics, 2012

[20] Khalique, M., Shaari, N., Abdul, J., Isa, A.H.B.M., Intellectual capital and its major components, 2011

[21] Bontis, N., Intellectual capital: an exploratory study that develops measures and models, In: Manag. Decis., 1998, $36,2,63-76$ 
[22] Bontis, N., National intellectual capital index: a United Nations initiative for the Arab region, In: J. Intellect. Cap., 2004, 5, 1, 13-39

[23] Chen, Q., Moghaddas, S.,Hoppel, C.L., Lesnefsky, E.J., Reversible blockade of electron transport during ischemia protects mitochondria and decreases myocardial injury following reperfusion, In: J. Pharmacol. Exp. Ther., 2006, 319, 3, 1405-1412

[24] Miller, R., Wurzburg, G., Investing in human capital, In: OECD Obs., 1995, 193, 16-20

[25] Ekanayake, N., Determinants of External Demand for Textiles and Garments of Sri Lanka, In: Staff Stud., 2016, 43, 1-2

[26] Qureshi, J.A., Jalbani, A.A., The role of public institutional support for globalization of pakistani companies, In: Pakistan Bus. Rev., 2017, 18, 4, 813-828

[27] Grewal, R., Slotegraaf, R.J., Embeddedness of organizational capabilities, In: Decis. Sci., 2007, 38, 3, 451-488

[28] Danneels, E., The dynamics of product innovation and firm competences, In: Strateg. Manag. J., 2002, 23, 12, 1095-1121

[29] Day, G.S., The capabilities of market-driven organizations, In: J. Mark., 1994, 58, 4, 37-52

[30] Autio, E., Sapienza, H.J., Almeida, J.G., Effects of age at entry, knowledge intensity, and imitability on international growth, In: Acad. Manag. J., 2000, 43, 5, 909-924

[31] Sapienza, H.J., Autio, E., George, G., Zahra, S.A., A capabilities perspective on the effects of early internationalization on firm survival and growth, In: Acad. Manag. Rev., 2006, 31, 4, 914-933

[32] Gunday, G., Ulusoy, G., Kilic, K., Alpkan, L., Effects of innovation types on firm performance, In: Int. J. Prod. Econ., 2011, 133, 2, 662-676

[33] Hsu, I.C., Sabherwal, R., From intellectual capital to firm performance: the mediating role of knowledge management capabilities, In: IEEE Trans. Eng. Manag., 2011, 58, 4, 626-642

[34] Qiao, P., Ju, X., Fung, H.G., Industry association networks, innovations, and firm performance in Chinese small and medium-sized enterprises, In: China Econ. Rev., 2014, 29, 213-228

[35] Soto-Acosta, P., Popa, S., Palacios-Marqués, D., E-business, organizational innovation and firm performance in manufacturing SMEs: an empirical study in Spain, In: Technol. Econ. Dev. Econ., 2016, 22, 6, 885-904

[36] Ceylan, C., Commitment-based HR practices, different types of innovation activities and firm innovation performance, In: Int. J. Hum. Resour. Manag., 2013, 24, 1, 208-226

[37] Camisón, C., Villar-López, A., Organizational innovation as an enabler of technological innovation capabilities and firm performance, In: J. Bus. Res., 2014, 67, 1, 2891-2902

[38] Alamdari, F., Fagan, S., Impact of the adherence to the original low-cost model on the profitability of low-cost airlines, In: Transp. Rev., 2005, 25, 3, 377-392

[39] Cingöz, A.,Akdoğan, A.A., An empirical examination of performance and image outcome expectation as determinants of innovative behavior in the workplace, In: Procedia-Social Behav. Sci., 2011, 24, 847-853

[40] Miller, W.L., Innovation for business growth, In: Res. Manag., 2001, 44, 5, 26-41

[41] Walker, R.M., Innovation and organisational performance: Evidence and a research agenda, In: Adv. Inst. Manag. Res. Pap., 2004, 002

[42] Kafouros, M.I., Buckley, P.J., Sharp, J.A., Wang, C., The role of internationalization in explaining innovation performance, In: Technovation, 2008, 28, 1-2, 63-74

\section{Authors:}

MUHAMMAD ZIA-UR-REHMAN ${ }^{1}$, SAJJAD AHMAD BAIG ${ }^{1}$, MUHAMMAD ABRAR², MUHAMMAD HASHIM $^{1}$, FIZA AMJAD ${ }^{1}$, IRFAN AHMAD BAIG ${ }^{3}$, MUHAMMAD USMAN ${ }^{1}$

${ }^{1}$ National Textile University, Faisalabad, Pakistan

2Lyallpur Business School, GC University Faisalabad, Pakistan

${ }^{3}$ Muhammad Nawaz Sharif University of Agriculture, Multan Pakistan

Corresponding author:

SAJJAD AHMAD BAIG

e-mail: sajjad.baig@hotmail.com 